\title{
47- Türkçe Sözlük’te Arapça kelimelerle kurulan birleşik sözlerin tasnifi
}

\section{Sawsan ABU HANNOUD ${ }^{1}$}

APA: Abu Hannoud, S. (2021). Türkçe Sözlük’te Arapça kelimelerle kurulan birleşik sözlerin tasnifi. RumeliDE Dil ve Edebiyat Araşttrmaları Dergisi, (25), 786-801. DOI: 10.29000/rumelide.1032532.

$\ddot{O} \mathbf{z}$

Türkler ve Araplar zamanla ortak coğrafi ve dinî paylaşımlar neticesinde birçok alanda etkileşim yaşamıştır. Türkler ve Araplar arasındaki bu etkileşimin en önemli alanını da dil oluşturmaktadır. Buna bağlı olarak, Türkçeye Arapça kelimelerin geçişi ilk başta dinî terimler ile daha sonra neredeyse her alanda olmuştur. Bu doğrultuda Türkçede Arapça harf, edat, cümle, şibh-i cümle ve deyim de alıntılandığı görülmüştür. Türk dili tarihinde Arapça kelimeler Türkçenin ayrılmaz bir parçası olarak kullanılmış, daha ötesi Arapça kök ve edatlardan yeni kelimeler de türetilmiştir. Türetilen bu Arapça kelimeler arasında, Türkçe kökenli veya başka bir yabancı dilden alınan kelime ile Arapça kelimeden oluşan birleşik sözler de bulunmaktadır. Temlikname ve günâş̧ı kelimelerindeki gibi. Temlikname birleşik kelimesindeki temlik Arapça, name ise Farsçadır. Günâş̧ık kelimesindeki de gün Türkçe, âşı ise Arapçadır. Araştırmacılar tarafından Türkçede bu tür birleşik sözler uğradıkları ses, anlam değişimi ve imla açısından incelenmiştir. Bu çalışmada ise Arapça alıntılarla kurulan birleşik sözlerin anlamları esas alınarak merkezlilik açısından tasnif edilmesi amaçlanmıştır. Bu amaçla son baskı Türkçe Sözlük'ten derlenen Arapça kelime ve Türkçe veya yabancı kökenli kelimeden oluşan birleşik sözlerin anlamları incelendikten sonra bu sözler iç merkezli, dış merkezli ve hem iç merkezli hem dış merkezli olarak tasnif edilmiştir.

Anahtar kelimeler: Birleşik sözler, türetme, Arapça kelimeler, Türkçe Sözlük

\section{Classification of compound words formed with Arabic words in Turkish Dictionary}

\begin{abstract}
Turks and Arabs have interacted in many areas because of common geographical and religious sharing over time. The most important part of this interaction between Turks and Arabs is language. Depending on this, the transition of Arabic words to Turkish was firstly in religious terms and then in almost every field. Hence, Arabic letters, prepositions, sentences, phrases and idioms are also cited in Turkish. In the history of the Turkish language, Arabic words have been an integral part of Turkish. Moreover, new words were derived with Arabic roots and prepositions. Among these Arabic words, there are also compound words which are consisting of Arabic words and others of Turkish or foreign origin words. As in words "Temlikname" and "Günâşık". In the compound word of temlikname, temlik is Arabic and name is Persian. In the word "Günâşık", gün "day" is Turkish, and âşık "lover" is Arabic. In Turkish, such compound words are examined in terms of sound, semantic change, and spelling. In this study, it is aimed to classify the compound words formed with Arabic citations in terms of centrality based on their meanings. For this purpose, after examining the meanings of the compound words which are consisting of Arabic words and others of Turkish or foreign origin words
\end{abstract}

Dr. Öğr. Gör., Ankara Yıldırım Beyazıt Üniversitesi, Dil Eğitimi Uygulama ve Araștırma Merkezi (Ankara, Türkiye), sawsan_abuhanod@hotmail.com, ORCID ID: oooo-0oo3-2378-2589 [Araştırma makalesi, Makale kaylt tarihi: 01.11.2021-kabul tarihi: 20.12.2021; DOI: 10.29000/rumelide.1032532] 
which are in the last edition of Turkish Dictionary, these words had been classified as endocentric, exocentric and both endocentric and exocentric compounds.

Keywords: Compound words, word formation, Arabic words, Turkish Dictionary

\section{Giriş}

Türkçede alıntı kelimeler arasında en çok Arapçadan alınma sözler bulunmaktadır. Son baskı Türkçe Sözlük'te, 6512 Arapça kelimenin olduğu tespit edilmiştir (TDK 2019: 2674). Bu sayıdan hareketle Arapça ve Türkçe arasındaki dil etkileşiminin yoğun olduğu açıç̧a görülebilir. Türkçede, Arapça kelimelerin kullanımı Cumhuriyet döneminde azalmasına rağmen etkinlik derecesini hâlâ korumaktadır. Türkçe Sözlük'te tespit edilen 6512 Arapça kelimenin yanı sıra Arapça ekler ile birleşmiş Türkçe kelimeler de vardır. Altun-i gibi. Ayrıca Türkçede, Arapça kelimeler içeren bazı deyimler de kullanılmaktadır. Ya herrü ya merrü gibi. Ancak bu tür deyimlerdeki Arapça unsurlar ve kelimeler, ayrıyeten Türkçe Sözlük’te belirtilmemesine rağmen Arapça kelimelerin sayısı yüksektir.

19. ve 20. yüzyılda her alanda yaşanan hızlı gelişim, Türkçede yeni kelime türetme gerekliliğini ortaya çlkarmıştır. O zaman da Türkler ilk olarak Arapça ile Farsça kelimelere ve unsurlara başvurmuşlardır. Hatta Arapça unsurlardan oluşan terkipler ve Arapçada olmayan ancak Arapça kabul edilen kelimeler bile türetilmiştir. Türklerin Arapçayı bu şekilde kullanmaları, onların Arapçayı ne kadar benimsediklerini ve iyi öğrendiklerini ortaya koymaktadır. Bazı Arapça kelimelerin (belediye gibi) Arapçadaki şu an kullanılan temel anlamlarının, Türkçeden geçtiği kanıtlanmıştır (Lewis, 2017: 307). Bazı kelimeler de Türkçede yeni kullanıldığı vezniyle (felaket kelimesi gibi) tekrar Arapçaya geçip Arapça sözlüklerde yer almıştır. Türklerin Arapçaya bir yabancı dil gözüyle bakmamalarının hem Türkçeyi hem de Arapçayı zenginleştirdiğini söylemek hiç de yanlış olmasa gerek.

Türkçede diğer dillerdeki gibi yeni kelime türetme, örnekseme, kısaltma, ödünçleme ve birleştirme gibi süreçler altında incelenebilir. Türkçede, eklemeler ve tamlamalar dilin özünü oluşturduğu için kelime türetmesinde birleştirme yöntemi de çok sı görülmektedir. Hatta birleştirme yöntemi Türkçenin sözvarlığını genişletmede en çok kullanılan yöntemlerden biridir (Eker, 2019: 322). Türkçe Sözlük’te genel anlamda "bir araya getirme" olarak kullanılan birleştirme, dilde, dilsel unsurları bir araya getirerek yeni kelimeler ve kavramlar türetmek anlamına gelmektedir. Birleştirme yönteminin sonucu olan birleşik kelimenin tanımı dilden dile farklılık göstermektedir. İngilizcede genel olarak Crystal (1997: 423), birleşik kelimeyi "Her biri bağımsız olarak kullanılabilen ögelerden oluşan bir dil birimi." olarak tanımlamıştır. Fakat tanımdaki “ögeler”in kelime, kök veya ek olup olmadığı belli değildir.

Türkçede, Özel (1977), Banguoğlu (1986), Korkmaz (1992), Vardar (2002), Ergin (2009), Gülensoy (2015) ve Eker’in (2019) birleşik kelime tanımlarına bakıldığında, “yeni bir kavram karşılamak üzere iki veya daha çok kelimeden oluşan söz birliği” olarak tanımlandığı görülür. İhtiyaç, birleşik sözlerin türetilmesine yol açan temel sebep olarak değerlendirilebilir. İster bilimsel alanlarda ister halk arasında ihtiyaç duyulduğu zaman dilde diğer kelimelere başvurularak birleştirme yöntemi ile yeni kelimeler türetilir. Bu kelimelerin bazılarının benimsenip birleşik bir kelime olduğu bile fark edilemeyebilir. Bazıları ise kullanılmadıkça unutulur ve yerine başka bir kelime kullanılır. Bu süreçte, birleşik sözler, dilde türetilmiş diğer kelimeler gibi ilk anlı oluşum, sonra kuramsallaşma ve en son sözlükselleşme aşamalarından geçmektedir. 
Birleşik sözlerin adlandırmada da sık kullanıldığı görülmektedir. Mesela Arapçada eskiden birleşik

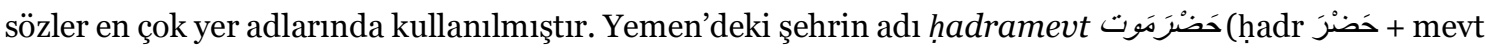
gَوْْت gibi (Hezim, 198: 2000). Hadr "gelmek, mevcut" demektir, mevt ise "ölüm" anlamında kullanılır. Bir rivayete göre hadramevt aslında bir adamın lakabıdır. Onun adı "Âmir bin Kahtân, o bir savaşa katıldığında (hadar) çok ölüm vakası (mevt) olduğu söylenmiştir. Böylece bu lakabı kazanıp sonradan kaldığı yerin ve kabilenin adı olmuştur². Adlandırmada Türkçede bitki adlarından örnek olarak günâşı (gün + âşık) "ayçiçeği” kelimesi verilebilir3. Birleşik sözler anlatılmak istenen nesnelerin şekilleri, sesleri ve genel olarak özelliklerinden faydalanarak türetilebilir. Türkçede bunun yanında bazen esprili bir anlatımdan faydalanarak birleşik sözler türetilebilir (Aksan, 2005: 172). "Özenle yapılmış” anlamındaki sinekkaydı kelimesi gibi. Bu kelime "erkeklerin özenle yapılmış sakal tıraşı” için kullanılmaktadır. Aksan, "Bu sıfat oluşturulurken adeta bir imge söze dönüştürülmüş, bir sineğin kayacağı ölçüde iyi tıraş edilmiş bir yüz anlatılmıştır.” şeklinde açıklamaktadır (2005: 176). Birleşik sözler Türkçenin söz varlığını zenginleştirerek anlatım yollarını da genişletmiştir.

Türkçede birleşik sözleri tarihî metinlerde çokça görmek mümkündür. Mesela, Divânü Lugâti’t-Türk dizininden şu örnekler verilebilir: agan er, kart er, karakuş, ve karabaş gibi (TDK, 2003). Türkçede birleşik sözlerin bazılarının ikisi Türkçe iken bazılarının ikisi de yabancı kökenli olabilmektedir. Bazıları ise biri Türkçe diğeri yabancı kökenlidir. İkisi Türkçe olan kelimeler soğukkanh (soğuk + kanlı) gibi. Mikrocerrahi (Fr. mikro) + (Ar. cerrahi) ise ikisi yabancı kökenli kelimelere örnektir. Biri Türkçe diğeri yabancı kelimeden oluşan birleşik sözlerden de günâş̧k (Tr. gün) + (Ar. âşık) kelimesi gibi.

Türkçede Arapça kelimeler ödünçleme yoluyla alındıktan sonra bazıları kelime türetme sürecinde de kullanılmıştır. Arapça kelimeler birleştirme yoluyla Türkçe veya başka yabancı kelimelerle birleştirilerek-yeni bir birleşik kelime olarak kullanılmıştır. Karaağaç’ın dediği gibi, "Alıntılar, bazen alıcı dilde, verici dilden daha geniş bir yaşama alanı bulabilirler.” (2017: 145). Bu durumun Türkçedeki Arapça alıntı kelimelerde de geçerli olduğu düşünülmektedir.

Türkçe Sözlük'te yaklaşık 2000 söz Arapça kelime ile ya da Arapça unsurla birleşmiştir. Bu çalışmada ise Arapça ve Türkçe ya da başka yabancı kelimeden oluşan birleşik sözler incelenecektir. Bu tür kelimeleri iç merkezli ve dış merkezli başlıklar altında tasnif edebilmek için ilk önce bu sınıflandırmalar kısaca açılanacaktır. Türkçe Sözlük’te (2019) yaklaşık 18o Arapça kelime ile kurulan birleşik söz tespit edilmiştir. Dolayısıyla bu çalışmada bütün kelimeleri incelemek zor olacağı düşünülerek örnek 25 kelime çalışmamıza dahil edilmiştir.

\section{1. İç ve dış merkezlilik çerçevesinde birleşik sözler}

Birleşik sözler anlamsal, yapısal ve sesbilgisel açılardan incelenmiştir. Bu doğrultuda farklı tasniflere tabi tutulmuş ve çeşitli alt başlıklara ayrılmıştır. Semantik olarak birleşik sözlerin anlamları değişip değişmediği ve ifade ettiği anlamın birleşik sözlerle ilişkisi üzerinde incelemeler yapılmıştır. Morfolojik olarak ise birleşik sözlerin ekle oluşup oluşmadı̆̆ı, öbek ile arasındaki ayrımlar gibi konular üzerinde farklı görüşler öne sürülmüş̧ür. Fonetik açısından birleşik sözler, birleştirme sürecinde yaşadığı ses kaynaşması, türemesi ve tonlulaşma gibi konular üzerinden incelenmiştir.

\footnotetext{
2 Hadramevt kelimesiyle ilgili bilgiler Mu 'cemu’l-Yâkût el-Hamevî çevrimiçi sözlüğünden ulaşılmıştır. Erişim adresi: http://arabiclexicon.hawramani.com/?p=139852\#f26561.

3 Aynı bitki için günebakan, gündöndü, ayçiçeği şeklinde farklı birleşik adlar kullanıldığı gibi meyvesine de ayçekirdeği dendiği malumdur.
} 
Bloomfield, birleşik kelimenin oluştuğu kelimelerin arasındaki ilişkiye göre birleşik kelimeleri iç merkezli ve dış merkezli olarak iki başlık altında sınıflandırmıştır. (1933: 235). Bu tasnifte kelimelerin anlamı esas alınmıştır. Hatta bu tasnif birleşik sözler için anlamsal açıdan temel bölümlerden biridir (Bauer, 64: 2017). İki kelimeden oluşan birleşik sözlerin bazılarında, kelimelerin biri temel kelime diğeri ise niteleyici sayılmaktadır. Temel, "hem konuşmanın bir bölümünü hem de bir bütün olarak birleşik kelime tarafından belirtilen anlamsal türü belirlemeye yarayan unsurdur." (Lieber, 2009: 46) Temel unsuru içeren birleşik sözlere iç merkezli sözler denir. Söz gelişi; sivrisinek (sivri + sinek) birleşik sözünde sinek kelimesi temel kelimedir. Sivri kelimesi ise sinek kelimesini tanımlayan niteleyici kelimedir.

Genelde iç merkezli birleşik sözlerin anlamları, birleşik sözünü oluştuğu kelimelerin anlamlarından tahmin edilebilir. Temel unsuru ile beraber olduğu kelime (niteleyici), temel unsurunun özelliğini (sıfat) veya türünü anlatmaktadır. Mesela, beyazsinek birleşik sözüne baktığımızda beyaz kelimesinin sineğin rengini işaret ettiğini görebiliriz. Zeytinyağı kelimesinde zeytin kelimesi yağın türünü belirtmiştir.

Temel unsuru olmayan birleşik sözler dış merkezli olarak adlandırılır. Dış merkezli kelimelerde temel unsuru olmadan birleşik sözünün oluştuğu iki kelimenin farklı bir anlam kazanarak benimsendiği görülmektedir. Mesela; delikanlı (deli + kanlı) kelimesinden oluşan deli ve kanl kelimelerinin niteledikleri nesne (kişi, kimse, erkek) bulunmamaktadır. Ancak bu kelime "çocukluk çağından çıkmış genç erkek / sözünün eri, dürüst, namuslu (kimse)” anlamlarında kullanılır.

Dış merkezli birleşik sözlerin anlamlarının genellikle, birleşik sözün oluştuğu kelimelerden tahmin edilmesi pek mümkün değildir. Dış merkezli kelimeler adeta eksiltmeye uğramışlardır. Çünkü dış merkezli birleşik sözün anlamı eğer bilinmiyorsa, anlamına ulaşlabilmek için dışarıda olan temel unsuruna ihtiyaç duymaktadır. Mesela, cumhuriyet kelimesinin anlamlarından biri "cumhuriyet altını"dır. Tabi eksiltme yoluyla cumhuriyet altın şeklinden sadece cumhuriyet kelimesi ile ifade edilebilir. Ancak okuyan / konuşan, bunu bilmeyen biri için cumhuriyet kelimesi ile birlikte altın kelimesini kullanarak anlatabilir. Aynı şeklide dış merkezli olan hoşsohbet birleşik kelimesindeki gibi. Hoşsohbet insan şeklinde kullanılırsa temel unsuru olan insan kelimesinden hareketle hoşsohbet kelimesinin anlamı sezilebilir. Ancak insan kelimesi olmadan hoşsohbet kelimesi "güzel sohbet" olarak algılanıp başka anlamda anlaşılır ve iç merkezli durumunda da bulunmuş olur. Unutulmamalıdır ki tüm iç merkezli birleşik sözlerin hemen anlaşllabildiği veya tüm dış merkezli birleşik sözlerin hiç anlaşılmadığı kati bir durum söz konusu değildir. Sarı, ögeler arasında doğrudan bir anlam ilişkisi içermeyen ancak aralarında sezilebilir bir ilişkisi olan birleşik sözleri yarı merkezli birleşikler başlı̆̆ altında tasnif etmeyi tercih etmiştir (2016: 209).

Bazı birleşik sözlerin, dış ve iç merkezli olduğu, kelimenin anlamlandırma yönünden belirlenebilir. Bazen de bakılan taraftan hem iç hem dış olma imkânını taşıyabilir. Mesela, İngilizcede, blue-bottle kelimesi harfen "mavi şişe" demektir. Ancak "mavi şişeye benzeyen bir böcek" anlamında kullanılır. Bloomfield bu birleşik kelimede eğer böceği şişe gibi sayarsak o zaman iç merkezli diye belirtir. Fakat eğer şişe sadece böceğin bir parçası olarak görülürse o zaman blue-bottle kelimesi dış merkezlidir (1933: 236). Ayrıca Bauer'in, dil ve sosyal değişiminden diş merkezli bileşiği olarak belirttiği diş merkezli birleşik sözlerin beşinci türünde, bazı birleşik sözlerin, kişilerin anlamlandırdıkları şekle göre hem $d \imath s ̧$ hem iç merkezli olduğu sonucu ortaya çlkmaktadır. İngilizcede bu kelimelerden biri blackberry "böğürtlen" kelimesidir. Bauer, blackberry (black: siyah + berry: dut) teknik ve bilimsel olarak bir meyve türü olan dut değildir. Dolayısıyla ona bir meyve olarak bakıldığından dış merkezli olur. Ancak bazıları blackberry'i bir dut tabağında bir dut çeşidi olarak görse o zaman blackberry, iç merkezli şeklinde ifade 
eder (2017: 67-68). Kişiden kişiye ve zamandan zamana kelimeyi anlamlandırmakta farklılık gösterildiği sürece anlam alanında kelimeleri tasnif etmek bu tür belirsiz durumlar oluşturabilir. Bizim çalışmamızda Türkçe Sözlük’te yabancı kökenli olarak derlenen kelimeler incelenirken, bazı kelimelerin iki farklı anlama sahip olup birinci anlamına göre değerlendirildiğinde iç merkezli, ikinci anlamına bakıldığında ise dış merkezli olduğu tespit edilmiştir. Dolayısıyla iç merkezli ve dış merkezli tasniflerin yanında hem iç merkezli hem dış merkezli tasnifin de eklenmesi uygun görülmüştür.

Dış ve iç merkezli başlığı altında yine alt tasnifler de bulunmaktadır. Mesela, Scalise ve Bisetto, niteleyici, strah ve tümleyen dış ve iç merkezli birleşik sözler olarak tasnif etmişlerdir (2005: 10). Bu tasnifin kapsamlı olduğu söylenebilir. Türkçede Birleşik Sözcükler (İsimler) adlı tezde, Türkçedeki kelimeler de Scalise ve Bisetto'nun tasnifleri esas alınarak sınıflandırılmıştır (Çürük, 2017: 95-121). Ancak bu tasnifler daha uzun bir çalışma gerektirdiği için bizim çalışmamıza dahil edilmeyecektir. Bundan dolayı çalışmada Türkçede Arapça ile birleşen yabancı kelime birleşik sözlerin temel unsurunun olup olmadığına göre iç ve dış merkezli tasnifler altında açıklanmıştır. Ayrıca kelimelerin anlamlarından hareketle bazı kelimelerin hem iç merkezli hem dış merkezli olabildiği tespit edilmiş ve o tür kelimeler hem iç merkezli hem dış merkezli tasnifi altında izah edilmiştir.

\section{Türkçe Sözlük’te Arapça kelimelerle ile kurulan birleşik sözler}

Bu bölümde Türkçe Sözlük’te Türkçe veya başka bir yabancı kökenli kelime ile birleşen Arapça asıllı kelimelerin oluşturduğu sözler incelenecektir. Aşağıda verilen birleşik sözler, bir ses olayı ve ek almaksızın bir araya gelerek teşekkül etmiş sözlerdir. Arapça ile birleşen kelimelerin çoğu Farsçadan alınmadır. Seyrek olsa da Arapça ile birleşen Fransızca ve İngilizce kelimeler de bulunmaktadır.

Birleşik sözler tasnif edilirken her bir sözün Türkçede ayrı olarak kullanıldığı zaman Türkçedeki anlamına bakılmıştır. Ayrı olarak kullanılmıyorsa kelimenin asıl anlamına ve birleştiği kelimeyle arasındaki ilişkisine göre değerlendirilmiştir. Arapça, Farsça ve Türkçe arasındaki dil farklılıklardan dolayı bazı kelimeler ses ve görev değişikliğine uğramıştır. Bu tasnifte kelimelerin uğradığı ses ve görev değişiklikleri göz ardı edilerek kelimeler, Türkçe kelimeler olarak değerlendirilmiştir. Ayrıca çalışmada bitişik olarak yazılan birleşik sözler tercih edilmiştir.4

\section{1. İç merkezli birleşik sözler}

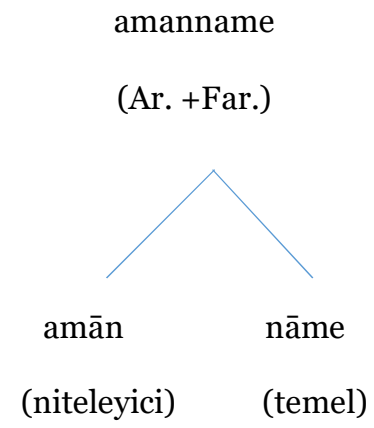

Türkçe Sözlük'te amanname "İslam devletlerinde düşmana güvenlik içinde olduğunu bildirmek üzere verilen belge" demektir. Arapçada aman "güven" anlamında kullanılır. Farsçada name "mektup, yazı"

4 Arapça kelimelerin anlamları, çevrimiçi olarak Almaany sözlüğünde araştırllmıştır. Erişim $\begin{array}{r}\text { adresi: } \\ \text { https://www.almaany.com/ar/dict/ar-ar/. Türkçe kelimelerin anlamlarına da çevrimiçi olarak Türkçe Sözlük'e }\end{array}$ bakılmıştır. Erişim adresi: https://sozluk.gov.tr/ 
demektir (1952: 645). Aman kelimesi, temel unsuru olan name kelimesini niteleyerek, bir türde (aman name) sınırlandırmıştır. Türkçede çocuk kitabı ve ders kitabı birleşiklerindeki gibi.

Türkçede iç merkezli olarak amanname kelimesine benzeyen kelimeler de vardır. Bahname, beyanname, celpname, davetname, ehliyetname, emirname $\mathrm{vb}$.

ameliyathane

(Ar. +Far.)

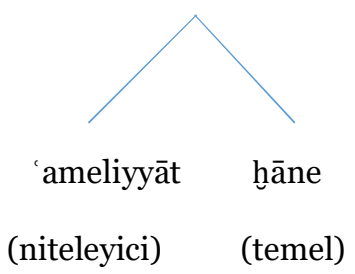

Türkçe Sözlük'te ameliyathane için "hastanelerde hastaların ameliyat edildiği özel bölüm” manası verilmiştir. Arapçada ameliyat "operasyon", Farsçada hane "ev, mesken, saray" anlamlarında kullanılır (Kanar, 1952: 252). Ameliyat kelimesi, hane kelimesini belirterek hanelerin biri olarak ifadesini vermektedir. Farsçada ameliyathane birleşik sözüne benzeyen kelimeler de vardır. Mesela, şerbethane "içki mahzeni" (Kanar, 1952: 383), şifahane "hastane" (Kanar, 1952: 386) ve şîrekhane "haşhaş salgısı içilen yer, meyhane" (Kanar, 1952: 395) gibi.

Türkçede, Farsça hane kelimesi ile birleşen kelimelerden fakirhane, fetvahane, gusülhane, gasilhane, halvethane, hapishane vb. de vardır.

akamber

$$
\text { (Tr. +Ar.) }
$$

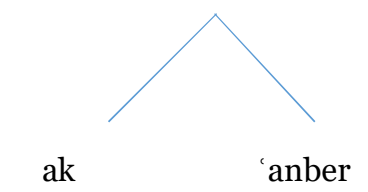

(niteleyici) (temel)

Akamber, Türkçe Sözlük'te “özellikle amber balığının bağırsaklarından çıkarılan, kül renginde, yapışkan, bükülgen ve misk gibi kokusu olan bir taş / sıcak ülkelerde yetişen bir ağaçtan elde edilen katı, güzel kokulu reçine" demektir. Türkçe $a k$ "beyaz, temiz, dürüst" anlamlarında kullanılır. Arapça amber ise "güzel kokulu madde" demektir. Amber kelimesi tek olarak Türkçede "amber balığından çıkarılan güzel kokulu, kül renginde bir madde / güzel kokulu bazı maddelerin ortak adı” demektir. Bu anlamlardan hareketle akamber, amber'in bir alt türü olarak değerlendirilebilir. Dolayısıyla amber, temel unsuru, ak kelimesi ise niteleyici olarak değerlendirilmektedir. 
asilzade

(Ar. +Far.)

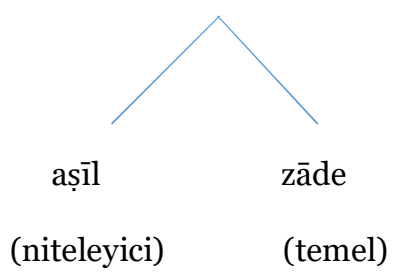

Türkçe Sözlük'te asilzade "soylu” demektir. Arapça asil "soylu, asaletli” anlaminda kullanılır. Zade ise Farsçada "oğul" demektir (Kanar, 1952: 325). Asilzade birleşik kelimesinde, zade kelimesi temel unsuru, asil kelimesi ise niteleyici olarak değerlendirmektedir. Farsçada asilzade birleşik sözüne benzeyen sözler de vardır. Ocakzade "soylu, asil" ve bozorgzade "asil" (Kanar, 1952: 104) gibi.

beddua

(Far. +Ar.)

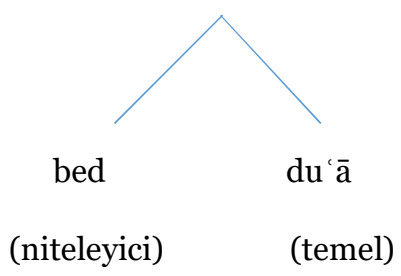

Türkçe Sözlük'te beddua "birinin kötü duruma düşmesini gönülden isteme5, ilenme, ilenç, kargış" demektir. Farsça bed "kötü" anlamındadır (Kanar, 1952: 95). Arapça dua Türkçedeki anlamıyla aynıdır. Bed kelimesi dua kelimesini nitelendirmektedir.

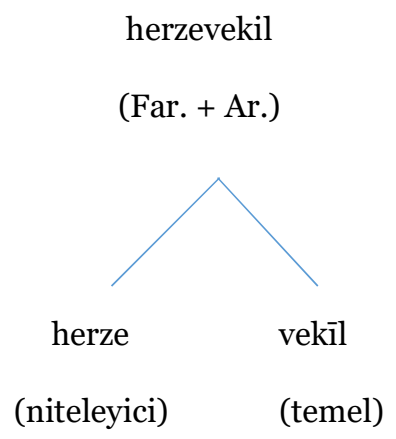

Türkçe Sözlük'te herzevekil "kendisini ilgilendirmeyen işlere karışan (kimse) / saçma sapan, gereksiz konuşan (kimse)" demektir. Farsçada herze "boş, yararsız, saçma, avare" anlamında kullanılır (Kanar, 1952: 688). Vekil ise Arapçada, Türkçe Sözlük’teki "birinin, işini görmesi için kendi yerine bıraktığı veya yetki verdiği kimse" anlamıyla aynıdır. Farsçada herzevekil kelimesine benzeyen birleşik kelimeler de vardır. Mesela, herzederây "boş konuşan, saçmalayan” ve herzekâr "faydasız işler yapan” (Kanar, 1952:

5 Aslında tanım "gönülden isteme" ile kalmayıp sözle ifade etme şeklinde olmalıdır: "Birinin kötü duruma düşmesini gönülden isteyerek söyleme, dile getirme." gibi. Sonraki kelime karşılıkları da malum olduğu üzere sözlüdür. 
688) gibi. Türkçede bu birleşik sözlerin etkisinden hareketle herzevekil kelimesi türetilmiş olabilir. Herzevekil kelimesindeki herze kelimesi vekil kelimesini nitelendirmektedir.

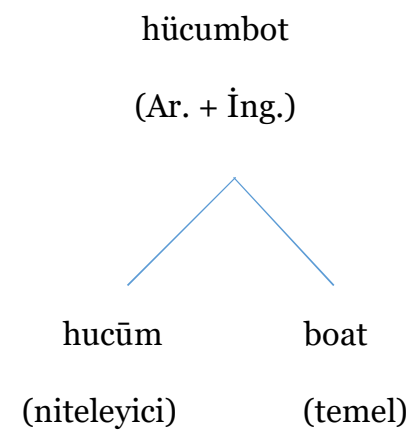

Türkçe Sözlük'te hücumbot için "görevi saldırmak olan, torpidolarla donatılmış, keşif ve karakol görevlerini de yapan, çok hızlı, küçük savaş gemisi” tanımı verilmiştir. Hücum Arapçada "saldırmak" anlamında kullanılır, Türkçeye de böyle geçmiştir. İngilizcede bot (boat) ise "gemi, vapur, sandal, yat gibi tekne" demektir (Redhouse, 2012: 161). Hücum (niteleyici) kelimesi bot (temel) kelimesi ile birleştirilerek botların bir alt türünü ifade etmektedir.

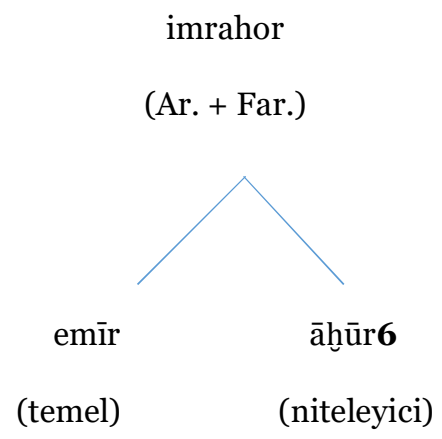

Türkçe Sözlük'te imrahor "padişah ahırlarına ve onlarla ilgili gereçlere bakmakla görevli kimse" demektir. Arapçada emîr "başkan, önder, prens, sorumlu", âhûr ise Farsçada "ahır" anlamında kullanılır (Kanar, 1952: 18). Farsçada imrahor kelimesine benzeyen mîrâhor kelimesi de vardır. Kubbealtı sözlüğünde bu kelimenin Far. emir-i āhūr'dan dönüştüğü yazılmıştır. Bu kelimede temel unsur sol taraftadır. Türkçede bu duruma rastlamak neredeyse mümkün değildir. Fakat bu birleşik kelimenin yabancı kökenli kelimelerden oluşması ve Farsça mantığına göre türetildiği değerlendirildiği için temel unsurunun solda olması normaldir. Türkçede imrahor kelimesini "ahır sorumlusu" olarak okuduğumuzda "sorumlu” anlamındaki emîr kelimesinin temel unsuru olduğu daha net görülebilir. Kamus-ı Türkî’de ahır kelimesinin aslı Türkçe olup Farsçaya geçtiği belirtilmiştir (2015: 36). O hâlde imrahor birleşik
sözü (Arapça ve Türkçe) kelimelerden oluşmaktadır. 


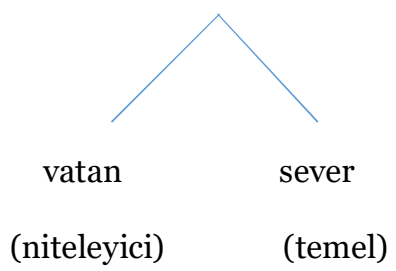

Türkçe Sözlük'te vatansever'e “yurtsever” anlamı verilir. Temel unsuru fiil veya fiilden türetilmiş olan birleşiklerde, niteleyici bir nesne olarak görülür (Lieber, 2009: 48). Yani vatansever kelimesinde vatan (nesne), sever (fiil, sifat fiil) olur. Bunun yanında vatan kelimesi, temel unsuru olan sever kelimesinin bir niteleyicisidir. Türkçede vatansever, Farsçadaki vatanperver (Arapça + Farsça) yapısından vatansever şeklinde dönüştürülmüştür.

ikrocerrahi

$$
\text { (Fr. + Ar.) }
$$

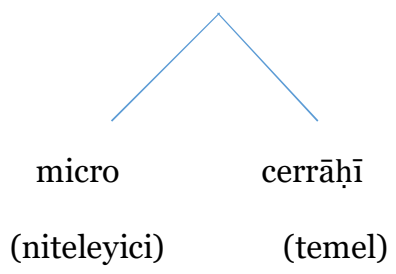

Mikrocerrahi Türkçe Sözlük'te "mikroskop altında çok özel araçlarla yapılan ameliyat” demektir. Fransızca mikro kelimesinin anlamı Türkçedeki ile aynıdır (Yıldız, 1997: 748). Arapça cerrahi ise "ameliyat yapan doktor" anlamındaki cerrah kelimesine mensuptur. Ancak cerrahi şeklinde Türkçedeki gibi kullanılmamaktadır. Kamus-ı Türkî̀de cerrahi kelimesinin Arapça "yara ile ilgili” anlamında kullanılan cirâhî kelimesi ile aynı olduğu ve Türkçede cerrâhî şeklinde okunmasının yanlış olduğu açıklanmıştır (2015: 178). Cerrahi kelimesi Farsçada da bu vezinde kullanılmaktadır. Cerrahi kelimesi Farsçadaki gibi “ameliyat" anlamında kullanıldı̆̆ farz edilerek bu birleşik kelimenin iç merkezli (mikro 'niteleyici' + ameliyat 'baş') olduğunu söylemek mümkündür. Bu doğrultuda mikro kelimesi, temel unsuru olan cerrahi kelimesini nitelendirmektedir.

sermuharrir

(Far. + Ar.)

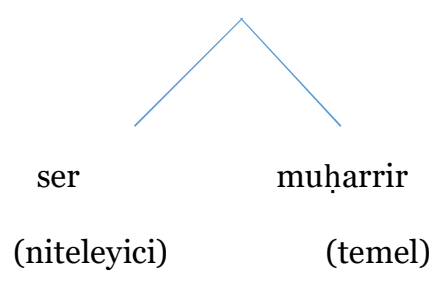


Türkçe Sözlük'te sermuharrir "başyazar" demektir. Farsçada ser "baş” (Kanar, 1952: 348), Arapçada muharrir "yazar, editör" anlaminda kullanılır. Ser kelimesi, temel unsuru olan muharrir kelimesini nitelendirmektedir. Türkçede sermuharrir kelimesine benzeyen sermürettip ve sertabip kelimeleri de vardir.

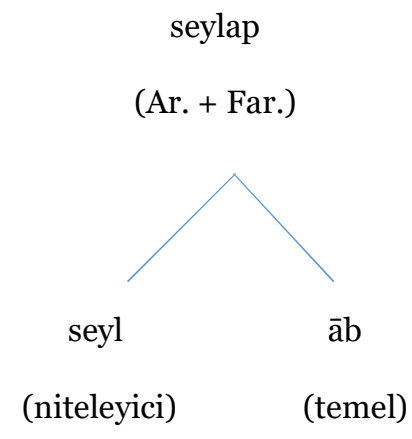

Türkçe Sözlük’te seylap “su baskını, taşma, taşkın, feyezan” demektir. Arapça seyl “su baskını”, Farsçada $\hat{a} b$ "su" anlamında kullanılır. Farsçada seylap birleşik olarak da kullanılmaktadır (Kanar, 1952: 375). Seylap birleşik kelimesi, Farsçada kullanıldığı şekilde ve anlamda Türkçede de kullanılmaktadır. Seylap birleşik kelimesinde seyl kelimesi, âb kelimesini nitelendirmektedir.

\subsection{Dış merkezli birleşik sözler}

bedava

(Far. + Ar.)

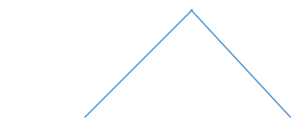

bād hevā

Türkçe Sözlük'te bedava kelimesi, "karşılıksız, parasız, emeksiz, caba, çok ucuz" şeklinde anlamlandırılmıştır. Farsçada bad "rüzgâr, yel, hava vb." (Kanar, 1952: 86), Arapça hava "rüzgâr, yel" anlamında kullanılır. Türkçede bu iki kelime birleşerek yeni anlam kazanmıştır. Bedava birleşik kelimesinde temel unsur bulunmamaktadır. Bed ve hava kelimelerinin "boşluk" anlamını verdiğinden ikisi beraberken Türkçede yeni anlamlar kazanmıştır. bed ve hava kelimesi başka (dış) bir temel unsuru nitelendirmektedir.

cilbent

(Ar. + Far.)

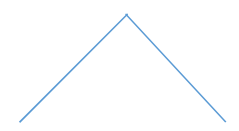

cild

bend 
Cilbent için Türkçe Sözlük’te "klasör" anlamı verilmiştir. Arapçada cild kelimesi “deri”, Farsçada bend kelimesi ise "bağ, ip, mafsal vb." demektir (Kanar, 1952: 113). Kubbealt sözlüğünde cilbent kelimesi, "cilbentlerin, içindekilerin daha iyi korunması için üst ve yan taraflarına tutturulan şeritlerle bağlandığı da olurdu” şeklinde kullanılmıştır. Türkçede cilbent adında kullanılan klasör, metalinden ve bağlama şeklinden esinlenerek "deri" anlaminda cilt ve "bağ" anlamında bend kelimesi ile birleştirilerek türetilmiştir. Bu iki kelime arasında anlamsal bir bağlantı bulunmadığı için dış merkezli tasnif altında değerlendirilmektedir.

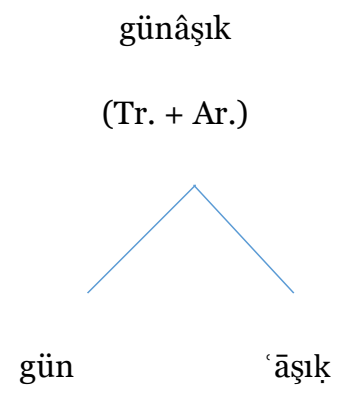

Türkçe Sözlük'te günâşık için verilen mana “ayçiçeği”dir. Eski Türkçede kün "güneş” anlamında kullanılmıştır. Türkçede gün ve âşı kelimeleri ayrı olarak farklı anlamlarda kullanılırken birleştiğinde, günâşık bitkisinin güneşi seven bir bitki olması özelliğinden esinlenerek yeni anlam kazandığı değerlendirmektedir. Gün ve âşık kelimesi başka (dış) bir temel unsuru nitelendirmektedir.

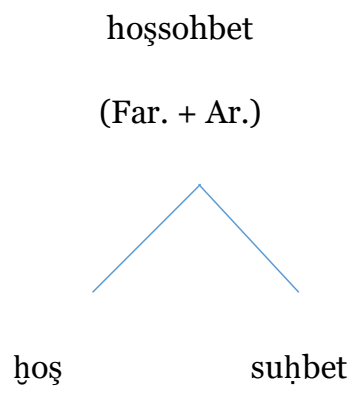

Türkçe Sözlük'te hoşsohbet "güzel ve tatlı konuşan (kimse)" anlamı verilmiştir. Farsçada hoş "hoş, güzel, iyi" (Kanar, 1952: 267), Arapçada sohbet ise "arkadaşlık" anlamında kullanılır. Hoş ve sohbet kelimeleri başka bir temel unsuru tavsif etmektedir.

\section{kalebent}

(Ar. + Far.)

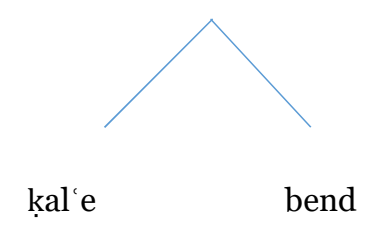

Türkçe Sözlük'te kalebent "kale dışına çlkmamaya hüküm giyen suçlu” şeklinde tanımlanan kelimenin yapısı, Arapça+Farsça şeklindedir. Arapça kale kelimesi Türkçedeki anlamıyla aynıdır. Farsçada ise 
bend “bağ, ip, mafsal vb." demektir (Kanar, 1952: 113). Kale ve bend kelimeleri başka (dış) temel unsuru nitelendirmektedir.

muhayyersümbüle

$$
\text { (Ar. + Far.) }
$$

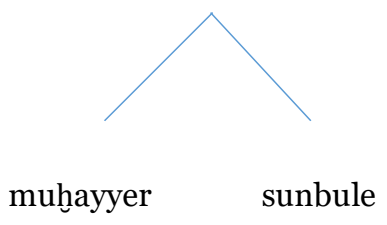

Muhayyersümbüle Türkçe Sözlük’te "klasik Türk müziğinde bir makam” şeklinde açıklanmış. Arapçada muhayyer "seçmekte hür, kendi iradesiyle hareket edebilen", Farsçada sümbüle "başak" (Kanar, 1952: 369) anlamında kullanılır. Muhayyer ve sümbüle kelimeleri arasında anlamsal bir bağlantı bulunmamaktadır. İkisi asıl anlamlarından farklı anlamda kullanılmaktadır. Ayrıca bu iki kelime birleşip başka (dış) bir temel unsuru nitelendirmektedir.

$$
\text { nalbant }
$$$$
\text { (Ar. + Far.) }
$$

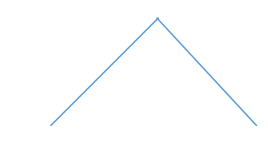

na'l

bend

Türkçe Sözlük'te nalbant "hayvanların ayağına nal çakan kimse" demektir. Arapça nal kelimesi Türkçe Sözlük'teki "at, eşek, öküz vb. yük hayvanlarının tırnaklarına çakılan, ayağın şekline uygun demir parçası” anlamıyla aynıdır. Bend ise Farsçada “bağ, ip, mafsal vb.” demektir (Kanar, 1952: 113). nalbant kelimesi Farsçada da kullanılmaktadır (Kanar, 1952: 656). Bu birleşik söz, hayvanların ayağına nalı yani özel bir çivi olan mıhı çakarak rapteden kimsenin yaptığı işten esinlenerek türetilmiştir. Nal ve bend kelimeleri başka (dış) bir temel unsuru nitelendirmektedir.

\section{neveser}

(Far. + Ar.)

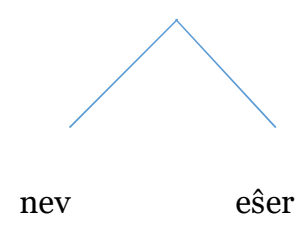

Türkçe Sözlük'te "klasik Türk müziğinde birleşik bir makam” şeklinde açlklanır. Farsçada nev "yeni, taze, vb." (Kanar, 1952: 463), Arapçada eser "iz, belirti” anlamında kullanılır. Nev ve eser kelimeleri, 
Türkçede birleşerek yeni anlam kazanmıştır. Ayrıca bu iki kelime birleşip başka (dış) bir temel unsuru vasıflandırmaktadır.

nevresim

(Far. + Ar.)

nev

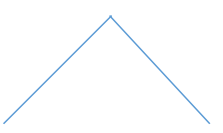

resm

Türkçe Sözlük’te nevresim için "torba biçiminde dikilmiş, yorgana geçirilen kılıf” tanımı verilmiştir. Farsçada nev "yeni, taze, vb.” (Kanar, 1952: 663), Arapça resm "çizim, iz" anlamlarında kullanılır. Neveser ve nevresim kelimeleri "yeni eser" ve "yeni resim" anlamlarında kullanılsaydı iç merkezli olurdu. Fakat iki kelime arasında anlamsal bir bağlantı bulunmadığı için dış merkezli tasnif altında değerlendirilmektedir.

$$
\text { safderun }
$$$$
\text { (Ar. + Far.) }
$$

șāf

derūn

Safderun kelimesine Türkçe Sözlük'te "kolayca aldatılan, saf" şeklinde mana verilmiştir. Arapça saf "katkısız, halis", derun ise Farsçada "iç, orta, dahil" anlamlarında kullanılır (Kanar, 1952: 283). Saf ve derun kelimesi, başka (dış) bir ögeyi nitelendirmektedirler.

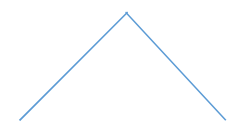

șāf

dil

Türkçe Sözlük’te safdil "kolayca aldatılan, saf (kimse)" demektir. Arapça saf "katkısız, halis”, Farsçada dil "yürek, iç, karın, can" (Kanar, 1952: 290) anlamlarında kullanılır. Bu birleşik kelime Farsçadan alıntılanmıştır. Saf ve dil kelimeleri birleşerek başka (dış) bir unsuru nitelendirmektedir. 


\subsection{Hem iç hem diş merkezli birleşik sözler}

Türkçede Arapça kelime ile kurulan bazı birleşik sözler birden fazla anlamda kullanılmaktadır. Bu durumda iç veya diş merkezli olarak tasnif edebilmek için birleşik kelimenin anlamları, oluştuğu kelimelerin anlamlarından doğrudan çözülebilip çözülemediğine ve temel unsurunun olup olmadığına bakılarak tasnif edilebilir. Ancak bazı birleşik sözlerin anlamlarından birine göre değerlendirildiğinde iç merkezli, diğer bir anlama göre değerlendirildiğinde ise dış merkezli olduğu tespit edilmiştir. Buna bağlı olarak bu bölümde Türkçe Sözlük'teki çok anlamlılık durumundan dolayı hem iç hem dış merkezli tasnif edilebilen kelimelerden örnek verilmiştir.

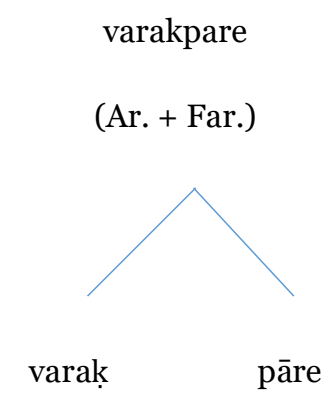

Türkçe Sözlük'te varakpare "kâğıt parçası" ve "mektup, name” demektir. Arapça varak "yapraklar", pare "parça, bölüm" (Kanar, 1952: 127) anlamında kullanılır. Bu kelimenin "kâğıt parçası" anlamına bakıldığında iç merkezli şeklinde tasnif edilebilir. Pare kelimesi temel unsuru ve varak kelimesi niteleyici, ancak "mektup, name" anlamı değerlendirildiğinde, varak ve pare kelimelerinin arasındaki anlam ilişkisi olmadığı değerlendirilerek dış merkezli tasnif altında yer verilmiştir.

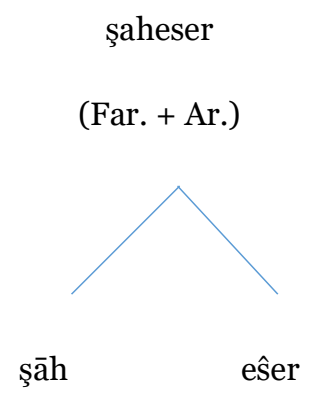

Türkçe Sözlük'te şaheser kelimesinin iki anlamı vardır; birincisi, "kendi türünde mükemmel olan, üstün ve kalıcı nitelikte eser, başyapıt, başeser", ikincisi ise "değeri üstün olan, üstün nitelikli” şeklindedir. Şaheser kelimesinin birinci anlamına bakıldığında iç merkezli olduğu anlaşılabilir. Eser kelimesi temel unsuru ve şah ise niteleyici olarak değerlendirilebilir. Ancak şaheser kelimesinin "değeri üstün olan, üstün nitelikli” anlamı ile düşünüldüğünde eser kelimesinin artık temel unsuru olmadığı anlaşılır. Mesela şaheser bir işlem denir. Burada eser kelimesi şah kelimesi ile cümlede başka bir temel unsuru tavsif etmektedirler.

\section{Sonuç}

Türkçenin ayrılmaz bir parçası olan Arapça kelimeler, Türkçede kelime türetme sürecinde diğer Türkçe kelimeler gibi başka kelimelerle birleşerek yeni kullanım alanları oluşturmuştur. Bu çalışmada Türkçe Sözlük'ün son baskısında yer alan Türkçe veya yabancı kelime ile birleşen Arapça kelimeler, merkezlilik 
açısından iç merkezli, dış merkezli ve hem iç hem dış merkezli başlıklar altında incelendikten sonra şu sonuçlara ulaşılmıştır:

1. Türkçe Sözlük’te Türkçe veya yabancı kelime ile birleşen Arapça sözlerin sayısı yaklaşık 18o’dir.

2. Türkçede Arapça kelimelerle birleşen kelimelerin çoğu Farsçadır.

3. Bazı birleşik sözlerin, Türkçede değil, Farsçada türetilip Türkçeye geçtiği ihtimali araştırılmalıdır. Bazı kelimeler ise Farsçadaki birleşik sözlere benzetilerek Türkçede türetilmiştir.

4. Türkçede genelde iç merkezli Arapça ve yabancı kelimeden oluşan birleşik sözlerde, Türkçedeki kelimeler gibi, temel unsur sağda bulunmaktadır. Fakat bazı birleşik sözler Türkçeye Farsçadan geçtiğinden dolayı seyrek olsa da bu sözlerde temel unsur solda olabilmektedir.

5. Birleşik sözlerin çok anlamlı olması, bir anlamına göre iç merkezli, diğer anlamına göre ise $d \imath$ ş merkezli olarak tasnif edilme durumunu ortaya çıkarmaktadır. Dolayısıyla bir birleşik kelime hem iç merkezli hem de dış merkezli şeklinde sınıflandırılabilir.

Son olarak Türk dili tarihinde Arapça ve Farsça gibi iki yabancı dilden kelime almak ve bu alıntılardan yeni sözler türetmek Türkçeyi zenginleştirmiştir. Bu durumun Türkçeyi keyif verici bir zenginliğe ve hayret edici anlamlar dünyasına ulaştırdığını söylemek mümkündür.

\section{Kisaltmalar}

Ar. Arapça

Far. Farsça

Fr. Fransizca

haz. hazırlayan

İng. İngilizce

s. sayfa

S. sayl

TDK Türk Dil Kurumu

Tr. Türkçe

Yay. yayımlayan

\section{Kaynakça}

Akalın, Ş. vd. (2019). Türkçe Sözlük. Ankara: Türk Dil Kurumu.

Aksan, D. (2005). Türkçenin Zenginlikleri İncelikleri. Ankara: Bilgi Yayınevi.

Ayver, İ. (2011). Misalli Büyük Türkçe Sözlük. İstanbul: Kubbealtı Yayınları. Erişim adresi: http://lugatim.com /.

Banguoğlu, T. (1986). Türkçenin Grameri. Ankara: Türk Dil Kurumu.

Bauer, L. (2017). Compounds And Compounding. New York: Cambridge University Press.

Bisetto, A. \& Scalise, S. (2005). Classification of Compounds. Linguee Linguaggio. S. 319-332.

Bloomfield. L. (1933). Language. New York: Allen \& Unwin. 
Crystal, D. (1997). The Cambridge Encyclopedia of Language. 2.baskl, Cambridge: Cambridge University Press.

Çürük, Y. (2017). Türkçede Birleşik Sözcükler (İsimler). Doktora Tezi, Ankara Üniversitesi.

Eker, S. (2019). Çağdaş Türk Dili. Ankara: Grafiker.

Ergin, M. (2009). Türk Dil Bilgisi. İstanbul: Bayrak.

Gülensoy, T. (2015). Türkçe El Kitabı. Ankara: Akçağ.

Hezîm, R. (2000). el-Terkîb el-Mezcî fi'l-Arabiyyati'l-Muasira. Mecelletu'l-Dirâsâti'l-Lugaviyye. Yemen, s. 193-207.

Kanar, M. (1952). Büyük Farça-Türkçe Sözlük. Tahran: Şirin.

Karaağaç, G. (2017). Dil Tarih ve İnsan. İstanbul: Kesit Yayınları.

Korkmaz, Z. (1992). Gramer Terimleri Sözlüğü. Ankara: Türk Dil Kurumu.

Lewis, B. (2017). Çağdaş Arapça'nın Siyaset Terminolojisinde Osmanlı Mirası. Elçin G (Yay. haz.). İmparatorluk Mirası Balkanlarda ve Ortadoğu'da Osmanlı Damgası içinde (s. 301-312) İstanbul: İletişim Yayınları.

Lieber, R. (2009). Introducing Morphology. New York: Cambridge University Press.

Özel, S. (1977). Türkiye Türkçesinde Sözcük Türetme ve Birleştirme. Ankara: Türk Dil Kurumu.

Redhouse (2012). İngilizce-Türkçe Sözlük (pdf). 10.10.2021 tarihinde Tebriz-Turuz sitesinden erişildi. Erişim adresi: https://turuz.com/book/title/Redhouse+IngilizceT\%C3\%BCrkce+S\%C3\%B6zl\%C3\%BCk+-+Redhouse-English-Turkish+Dictionary.

Sarı, İ. (2016). Türkiye Türkçesindeki Birleşik Sözcüklerin Merkezlilik Odağında Sınıflandırılması. Dil Araştırmaları. S. 18, s. 199-217.

Şemsettin Sami (2015). Kamus-ı Türkî. (haz. Yavuzarslan, P.) Ankara: Türk Dil Kurumu.

The Arabic Lexicon. Mu 'cemu'l-Yâkût el-Hamevî. Erişim adresi: http://arabiclexicon.hawramani.com/?p=139852\#f26561 (15.10.2021).

Türk Dil Kurumu (2003). Divanü Lugati’t-Türk Dizini. Erişim adresi: https://altaica.ru/LIBRARY/turks/Mahmud_turkish_index.pdf.

Vardar, B. (2002). Açıklamah Dilbilim Terimleri Sözlüğü. İstanbul: Multilingual

Yıldız, M. (1997). Fransaca - Türkçe Sözlük. Erişim adresi: https://turuz.com/storage/Dictionary/2018/1040-Fransizca-Turkce_Sozluk-Mustafa_Yildiz1997-1350s.pdf. 